\title{
TILL WE HAVE FACES AS MYTH AND ALLEGORY
}

\section{Mark Edwards}

Till We Have Faces is widely regarded by admirers of C.S. Lewis as his best work of fiction, and also the most enigmatic. While it is not obviously didactic, most readers have a sense that a meaning lurks in it that cannot be ascertained by a conventional analysis of the plot, the observations of the narrator and her developing awareness of her own motives. All these have in fact been examined in perceptive studies, as has the relation between the plot and its Latin precursor. The application of literary theory has been canvassed, ${ }^{1}$ and quotations from Lewis's theological writings have been set beside their counterparts in the novel; but seldom have critics taken more than perfunctory notice of the book's subtitle, $A$ Myth Retold. ${ }^{2}$ Although the term myth is variously defined - and Lewis's own definition will be considered below - the statement that a myth is a story retold from one generation to another will not be contested. We may reasonably hope, then, that a review of mediaeval and modern variants of the tale, including those which come in the guise of interpretations, will at least throw into relief the originality of Lewis, and may also enable us to recover some of the primitive matter from the "ferment" 3 of forty years which preceded the publication of the novel in 1956. It will also be argued here that the veil, by common agreement the most arresting and pervasive symbol in the novel, has a history distinct from, and even longer than, that of the principal narrative: its origin is to be sought in the Christian revelation, of which, according to Lewis, all other myths are but shadows. ${ }^{4}$ The conclusion will be that Till We Have Faces, like its prototype in Apuleius, demand a reading that may fairly be called allegorical, though only in a limited sense which allows for a delicate interplay of images and the self-assertion of the human characters as beings of

\footnotetext{
${ }^{1}$ M.E. Donaldson, Holy Places are Dark Places: C.S. Lewis and Paul Ricoeur on Narrative Transformation (Boston: Boston University Press, 1988); idem, "Orual's Story and the Art of Retelling: A Study of Till We Have Faces", in P.J. Schackel and C.A. Huttar, Word and Story in C.S. Lewis (Eugene, Oregon: Wipf and Stock, 2008), 157-170.

${ }^{2}$ D.T. Myers, Bareface: A Study of C.S. Lewis's Last Novel (Columbia, MO: Missouri University Press, 2004) takes a psychological approach, relating the story to other myths but not to other versions of the tale of Cupid and Psyche.

${ }^{3}$ Quoted by P.J. Schakel, "Till We Have Faces", in M. Ward and R. MacSwain (eds), The Cambridge Companion to C.S. Lewis (Cambridge: Cambridge University Press, 2010), 282.

${ }^{4}$ Cf. P.J. Schakel, Reason and Imagination in C.S. Lewis: A Study of Till We Have Faces (Grand rapids: Eerdmans, 1984), 64-65.
} 
flesh and blood. Indeed, it will be argued that the question, what it means to be flesh and blood, is the one that has given shape and purpose to the book.

\section{Is "Cupid and Psyche" a myth?}

The original tale is an exquisite digression in the Metamorphoses, or Golden Ass, of Lucius Apuleius. ${ }^{5}$ The hero of this picaresque romance has been transformed into an ass for his curiosity, and it is in this form that he hears an old woman recounting the consequences of a similar trespass. Psyche, the youngest and most beautiful of a king's three daughters, is worshipped by the populace as Venus on earth (4.32). The true Venus takes offence, and instructs her son Cupid to punish Psyche. Soon an oracle warns the king that great calamity can only be averted by exposing Psyche as prey to an unnamed monster (4.33-35). She is duly abandoned by a precipice, but the west wind conveys her to a gorgeous palace, where she is fed and dressed by unseen hands and shares the bed of a bridegroom who remains equally invisible (5.2-4). To complete her bliss, she requests that he sisters be enabled to visit her (5.6-8). On two successive occasions he gives them contradictory descriptions of her lover. Envying her good fortune, they use her ignorance to ruin her, alleging on their third visit that her husband is known to be a terrible serpent, whom she must kill before he devours her (5.12-20). That night, knife in hand, she lights an oil-lamp in the bedchamber, only to discover that her groom is Cupid himself (5.21-22). A drop of burning oil wakes him, and he deserts her, though promising that she will bear his child (5.23-24). Driven into the world, she is about to drown herself, but is dissuaded by Pan (5.25). Instead she first takes revenge on her sisters, telling each in turn that Cupid desires her for his new consort (5.2627). Each throws herself from the precipice, expecting the wind to sustain her, and is dashed to death.

Psyche meanwhile seeks refuge with Juno and Ceres, but is forced at last to throw herself on the mercy of Venus, who sets her a series of impossible tasks (5.28-6.9). The first - to winnow the different species of grain from an indiscriminate mass - is performed by ants (6.10). The second - to gather a handful of golden wool from a flock of ferocious sheep - is accomplished, on the advice of a river, by plucking the wool from briars which the sheep have touched in passing (6.12). The third - to procure a jar of ice-cold water from the

\footnotetext{
${ }^{5}$ See the edition of E.J. Kenney, Cupid and Psyche (Cambridge: Cambridge University Press, 1990).
} 
Stygian marshes - is accomplished by an eagle (6.15). The fourth is to descend to the underworld and return with a box containing a portion of Proserpina's beauty. Psyche is about to throw herself from a tower when the tower itself describes the itinerary that she must follow (6.17-19). Avoiding the temptations of which the tower has forewarned her, she procures the box, but on returning to the upper world, succumbs to curiosity, opens it and falls into a swoon (6.20). She is rescued by Cupid, Venus is reconciled and the story ends (6.24) with the birth of her child Voluptas (pleasure).

Lewis suggests in his preface that Apuleius was the transmitter, not the inventor, of the tale. ${ }^{6}$ In a typically imperious chapter on myth in his Experiment in Criticism, Lewis maintains that literary readers can derive from certain stories a pleasure independent of the author's handling of them even if, like the "Orpheus and Eurydice" of Virgil or the Norse myths retold by Snorri Sturluson in the Younger Edda, they have been handled at least once with unusual art. ${ }^{7}$ Such stories are recognisable when we reduce them to a synopsis and discover that they have not lost power to move us; by contrast, the plots of the Odyssey and Middlemarch are dead to us when we take away the literary dress. ${ }^{8}$ When we read it in its various redactions we come away with a higher appreciation of the myth as myth, not merely with the "highest common factor" that we obtain when (for example) we collate Shakespeare's play of Romeo and Juliet with its undistinguished source. ${ }^{9}$ Lewis does not insist that a myth should have no author, though the majority of those that he cites are evidently older than any source that now preserves them; even where the perennial form is known to be the creation of one great intellect, the poignancy which the myth retains in every new rehearsal does not depend upon our knowledge of this fact. We must assume that Cupid and Psyche satisfies this definition of myth, notwithstanding the absence of any allusion to it in An Experiment in Criticism, and notwithstanding the silence of all the mythographers whom Lewis names as witnesses to the durability of the ancient stories, from Natalis Comes to Roger Lancelyn Green. ${ }^{10}$

\footnotetext{
${ }^{6}$ TWHF, 7.

${ }^{7}$ Lewis, An Experiment in Criticism (Cambridge: Cambridge University Press, 1961), 44 and 46.

${ }^{8}$ Experiment, 40; cf. 61-62 on the quotidian character of Middlemarch.

${ }^{9}$ Experiment, 43.

${ }^{10}$ Experiment, 43.
} 
While elements of folklore and myth are easily discernible in the story, ${ }^{11}$ there is no good reason to doubt that Apuleius was the first to synthesize them. Sculptures of the amorous pair were common enough, and a scene in which it is Love who holds the lamp (not Psyche, as in Apuleius) was familiar both to Plotinus and to the author of a magical papyrus; $^{12}$ for that very reason, neither tells us more. Even motifs in the narrative which strike the modern reader as stereotypical were not so in antiquity: there is no ancient Cinderella who suffers injury or ill-usage at the hands of her elder sisters, and no ancient fable of Beauty and the Beast, though Zeus was wont to take bestial form for the pleasure of one night with a mortal. Where the adaptation of some older myth is visible, it is not always a Greek one. ${ }^{13}$ Thus, while expeditions to the nether world were recounted in Greece as in all other lands, the attempt of Venus to capture a portion of Proserpina's beauty is prefigured in none of these, but in the Mesopotamian story of Ishtar's descent to challenge her sister Ereshkigal, sovereign of the dead; ${ }^{14}$ Ishtar wins freedom only by giving up her human spouse, whereas Venus spares herself danger at the outset by appointing a human proxy. In Psyche's reluctant wanderings one scholar sees an analogue to the persecution of lo by Hera, the jealous wife of Zeus; ${ }^{15}$ Io is a Greek heroine, but to complete his interpretation he identifies her as a lesser form of Isis, the saviour of Osiris in Egyptian myth and also the saviour of Lucius, the hero of the novel in which "Cupid and Psyche" appears as an inset tale.

A myth in Greek philosophy is a shadowy or conjectural representation of possible truths which in the present world lie beyond the horizon of knowledge or the powers of common speech. The most famous narratives of this type in antiquity were those of Plato and Plutarch; alone of Latin authors, Apuleius is reckoned among the middle Platonists on his strength of his writings On Plato, On the World and On the Daemon of Socrates. We can hardly be surprised, then that the first reference in literature to his tale of Cupid and Psyche is accompanied by a Platonic interpretation, notwithstanding the Christianity of its author.

\footnotetext{
${ }^{11}$ R. Reitzenstein, Das Märchen von Amor und Psyche bei Apuleius (Leipzig: Teubner, 1912).

12 Plotinus, Enneads 3.5.9; Papyri Graecae Magicae 4.1725-1733.

${ }^{13}$ Though Psyche's exposure resembles that of Andromeda, and Venus has exchanged roles with the inexorable Juno of the Aeneid.

${ }^{14}$ S. Dalley, Myths from Mesopotamia (Oxford: Oxford University Press, 1989), 155-162. See below on the name Istra in Lewis.

${ }^{15}$ R. Merkelbach, "Eros and Psyche”, Philologus 102 (1953), 103-116.
} 
Fulgentius quotes a reading (perhaps not his own) which identifies the three sisters with the three parts of the soul in Plato, substituting flesh for bodily appetite, freewill for the selfregarding desires and spirit for rationality. ${ }^{16}$ Venus is concupiscence (the commonest sense of the word in Latin), which employs the covert suggestions of flesh and free will to overcome the initial reluctance of spirit to look on the sensual object; the lamp represents the kindling of desire. Boccaccio pursues a similar allegory in his Genealogy of the Pagan Gods. ${ }^{17}$ The three sisters correspond to the vegetative, the sentient and the rational elements of the soul or spirit, Psyche being the youngest because the rational is the last element that matures as we grow from childhood to years of majority. The sisters marry first because their desires can be satisfied in this world; the true object of reason is God, whom it apprehends by faith alone until the base desires persuade it to covet knowledge through natural vision. Her feeble lamp, however, merely estranges her from God without revealing him, and reunion is possible only after an arduous pilgrimage of contrition, the joyful outcome of which is represented by the child Voluptas.

Boccaccio has forced a Christian harness on the pagan myth, but not without ancient warrant. "My eros is crucified" wrote Ignatius of Ignatius of Antioch, ${ }^{18}$ and whatever he meant Dionysius the Areopagite took eros to signify Christ. In a poem entitled "The Crucifixion of Cupid" by Ausonius, a Christian writer of the fourth century, the god is executed by a mob of indignant victims of love, for sins not his own, in the presence of his mother. ${ }^{19}$ Eros is the word used of the soul's desire for Christ in allegorical commentaries on the Song of Songs, where the female protagonist roams the streets of Jerusalem in search of her lost beloved. More than one scholar suspects that Apuleius himself was acquainted with an early Christian essay in allegory, the Gnostic myth of the fall of Sophia. ${ }^{20}$ The last of thirty aeons or emanations from the inscrutable Father, Sophia is a symbol of the arrogance with which human wisdom seeks the knowledge of things beyond our powers of comprehension.

\footnotetext{
${ }^{16}$ Fulgentius, Mythologies 3.6 = Opera, ed. R. Helm (Leipzig: Teubner, 1970), 69.

${ }^{17}$ G. Boccaccio, Genealogy of the Pagan Gods, ed. and trans. J. Solomon (Cambridge, Mass.: Harvard University press, 2011), 285-295.

18 Romans 7, in M. Holmes, The Apostolic Fathers (Grand Rapids: baker, 2007), 232.

${ }^{19}$ Ausonius, Works, ed. R.P.H. Green (Oxford: Clarendon Press, 1991), 139.

${ }^{20}$ K. Dowden, "Psyche and the Gnostics", in B.J. Hijmans and V. Scmidt (eds), Symposium Apuleianum Groninganum (Gronigne: Klasiek Institut van der Rijksuniversiteit, 1981), 157-165; M.J. Edwards, "The Tale of Cupid and Psyche", Zeitschrift für Papyrologie und Epigraphik 94 (1992), 77-94; P. Cox Miller, "Plenty Sleeps There: The Myth of Eros and Psyche in Plotinsu and Gnosticism", in R.T. Wallis and J. Bregman (eds), Neoplatonism and Gnosticism (New York: SUNY Press, 1992), 223-238
} 
Banished in consequence from the pleroma or fullness of the Godhead, she works out her salvation by enlightening the denizens of the nether world which her tears brought into being, and provides them with a saviour by the clandestine mothering of a divine child on her own son, the tyrannical Demiurge.

The comparison is fruitful only if we assume, with the structuralists, that the permutation of motifs is part of the natural history of myth, and, with C.G. Jung, that psychoanalysis holds the key to the understanding of Gnostic thought. Of the six Jungian interpretation so "Cupid and Psyche" which are listed by Joel Relihan, ${ }^{21}$ the most seminal is that of Erich Neumann, ${ }^{22}$ for whom the darkness in which Psyche encounters Cupid represents the unselfconsciousness of woman in her primitive subordination to man, while the jealous sisters personify the painful awakening of her sense that "this is I". The resultant severance leaves both man and woman incomplete, and in decoding the subsequent peregrinations of Psyche we follow the stages of reconciliation which are crowned at last by a hermaphroditic fusion of two in one. Each of the first three tasks acquaints Psyche with Eros in a new aspect, first in the seed, then in the radiance of the wool, then in the energy of the waters; to each she contributes more of her own strength working with masculine forces, while in the fourth her individuated love encounters the Eternal Feminine. As her light wounded Eros and drove him away, so her fall into slumber calls him back to her, bringing forth his manhood, so that their reconciliation not only elevates the human but humanises the divine.

Psyche describes her husband once as an elderly merchant and once as a youthful hunter; competing speakers in Plato's Symposium tell us that love is the oldest and the youngest of the gods. ${ }^{23}$ Proverbially, love is a hunter, and in the Greek novel Daphnis and Chloe he reveals himself to the poet Philitas as both a man and a child. Psyche's relation to Venus has been likened to that between the Pandemic and the Uranian Aphrodite in Plato; ${ }^{24}$ yet Venus in Apuleius is more a fiend than a goddess, and her persecution of Psyche mirrors fortune's cruel sport with the hero of the Golden Ass. Philosophy compared itself to the

\footnotetext{
${ }^{21}$ J.C. Relihan, Apuleius: The Tale of Cupid and Psyche (Indianapolis: Hackett, 2009), 87.

${ }^{22}$ E. Neumann, Amor and Psyche: The Psychic Development of the Feminine (New York: Bollingen, 1956).

${ }^{23}$ Plato, Symposium 178a and 195c-d. For a Platonic reading of the narrative see C. Schlam, Cupid ad Psyche: Apuleius and the Monuments (University Park, PA: American Philological Association, 1976).

${ }^{24}$ Symposium 180c-181b.
} 
mysteries as a means of liberating the soul from the play of external forces; if the descent of Psyche to the underworld is a fictional representation of a mystery, ${ }^{25}$ her story will be a specimen of the sacred tales which accompanied such performances. And if that is so, it fits the anthropologist's definition of a myth.

\section{Earlier variations on Apuleius}

One account of myth, which would be consonant not only with modern literary theory but with Lewis's proposal to judge a text by the response that it elicits from its readers, would define it as a story that is frequently retold, with variations. This definition, with the final caveat, would exclude such novels as Pride and Prejudice or Oliver Twist, but would extend the status of myth to Faust, Don Juan and Frankenstein. It does not quite match the history of Cupid and Psyche in English, for the most celebrated versions in verse and prose have differed little from the original. ${ }^{26}$ The classic renderings into English prose by The sybaritic verses of William Browne, in the third book of Britannia's Pastorals (1625), add many new conceits but little new matter, and stop short well before the end of the tale. ${ }^{27}$ It was left to the French poet Jean de la Fontaine to give the tale the dimensions of a novel by the insertion of long verse interludes and passages of luxuriant description. He also resolved a mystery, for Apuleius never explains what caused the swoon of Psyche after she opened Proserpina's casket; in the French she is dismayed by the sudden change of her complexion from white to black. ${ }^{28}$

In the hands of three European writers - Giambattista Basile, ${ }^{29}$ Gabrielle-Suzanne de Villeneuve ${ }^{30}$ and Jeanne-Marie Leprince de Beaumont ${ }^{31}$ - the fable was transformed into

\footnotetext{
${ }^{25}$ The thesis was applied to the entire novel as early as W. Warburton, The Divine Legislation of Moses, vol. 2 (London: Gyles, 1741), 118-130.

${ }^{26}$ W. Adlington, The Golden Asse of Apuleius (London: Remainder Centre, no date), 89-121 (originally published in 1566). S. Marmion, "The Legend of Cupid and Psyche", in G. Saintsbury (ed.), Minor Poets of the Caroline Period, vol. 2 (Oxford: Clarendon Press, 1906), 6-60. W. Pater, Marius the Epicurean (London: Dent. 1932), 33-52. R. Bridges, Poetical Works (London: Oxford University Press, 1964), 87-184. G.R. Woodward, Cupid and Psyche, from the Latin of Apuleius (London: Herbert Daniel, 1912).

${ }^{27}$ W. Browne, Whole Works, ed. W.C. Hazlitt (Hildesheim: Olms, 1970), vol. 2, 183-189.

28 J. de la Fontaine, Les amours de Psyché et de Cupidon (Paris: Librairie Générale de France, 1991), 207. The original was published in 1669.

${ }^{29}$ G. Basile, The Pentameron, trans. R. Burton (London: Kimber, 1952): 134-142 (day 2, story 5); $162-66$ (day 2, story 9); 361-369 (day 5, story 4).

30 J. Zipes, Beauties, Beasts and Enchantment: Classic French Fairy Tales (Maidstone: Crescent Moon, 2009), 153-232.

${ }^{31}$ Zipes, Beauties, Beasts and Enchantment, 233-245.
} 
the nursery-tale of Beauty and the beast. When the English poet William Morris returned to the original, he fused it with another Greek myth in which the goddesses Hera, Athena and Aphrodite strive for the prize of beauty. Psyche is the image of Venus, as ever; when her sisters conspire against her in Cupid's palace, the elder surveys its riches with the jealous eye of Hera, while the younger alludes to her own skill with Athena's instrument, the ivory shuttle. ${ }^{32}$ In case the parallel should be lost on us, Morris attributes the breach between Psyche and Cupid to Eris, the goddess of discord who "threw the golden apple down/Upon the board, and lighted up Troy Town". ${ }^{33}$ Lewis may not have remembered the poem well, for he wrongly asserts in his preface that it follows the Latin "closely"; but he seems, as we shall see, to have taken to heart Cupid's valedictory confession that a god does not know how to heal a mortal's pain. ${ }^{34}$

There is no allusion to Hera, Athena or Aphrodite in the novella called Psyche by Louis Couperus. ${ }^{35}$ Yet Psyche lives in awe of her eldest sister Emeralda, who never speaks but to command, and thinks her other sister Astra wiser than all the philosophers (pp. 1718). The youngest of the three, she is always naked, and the wings that sprout from her shoulders are too slight to bear her aloft from the high-towered castle of her father, where she often has only birds and butterflies for company (p. 25). Suddenly she is befriended by the chimaera, a flying horse who bears her to regions of impossible desire (pp. 28-34). Consequently, she at first declines the overtures of Eros, a neighbouring prince (pp. 42-43). When she is abandoned by the chimaera in the desert, close to the Sphinx, Eros finds her again and conducts her to his palace (pp. 62-76). There she dwells serenely, as queen of the present, while Emeralda succeeds their father, breeding spiders in the kingdom of the past (pp. 58; 77-83). One day, however, she yields to the enticements of a satyr, and when she returns from his revels Eros is dead and the palace overrun by the spiders of Emeralda ( $p p$. 101-120). To atone for her infidelity, she returns as a willing slave to Emeralda, ${ }^{36}$ who commands her to fetch a magnificent jewel form the underworld (p. 136). She accepts this mission in the hope of saving Astra, whose gazing at the stars has made her blind (p. 139). In contrast to the Psyche of Apuleius, she brings back not the jewel, but the news that it exists

\footnotetext{
32 W. Morris, "The Story of Cupid and Psyche", The Earthly Paradise (London: Longmans, 1903), 106.

${ }^{33}$ Earthly Paradise, 108.

${ }^{34}$ Earthly Paradise, 110: "though I, a god, can never know/How thou canst lose thy pain".

${ }^{35}$ L. Couperus, Psyche, trans. B.S. Berrington (London: Pushkin Press, 1999). Dutch edition 1898.

${ }^{36}$ On p. 134 she stands naked before her, like Ishtar before Ereshkigal: Dalley (1989), 171.
} 
only in the vanity of her sister (pp. 151-169). The enraged Emeralda rides her down with her chariot and drives on implacably, mowing down all in her path, until she reaches the desert and dashes herself to pieces against the impassive Sphinx (pp. 170-174). Psyche revives and is carried by the chimaera into vertiginous realms of the future, where she is reunited with her father and Eros (p. 178). Astra regains her vision, and dies in peace (p. 179).

This is not an interpretation of Apuleius but a new allegory, speciously Platonic but essentially modern, in which the soul escapes not from the prison of time to her true home in eternity, but from the past and the present into the unwritten future. Her steed - we know the meaning of "chimerical" - represents aspirations that could not have been framed, or framed in such terms, before the nineteenth century. A modern psychoanalyst (though the term would not be available to Couperus) would construe the death of Eros as the overcoming of the "nirvana principle", a necessary stage in our adaptation to social life. Published in 1898, the year of Lewis's birth, this book is a bridge, for those who wish to cross such waters, between Apuleius and Freud.

\section{The story in Lewis}

In plot Till We Have Faces resembles none of these imitations. Its novelty is apparent on the first page, where the writer identifies herself as Orual, daughter of the king of Glome, and an accuser of all the gods (p. 11). Her narrative begins with a recollection of her infancy, when a Greek tutor, nicknamed the Fox, is appointed for her and his younger sister Redival (p. 12). The next episode is the marriage of her widowed father to a second wife, who dies in childbed (p. 27). She leaves behind her a daughter of godlike beauty, whose name Istra ${ }^{37}$ means Psyche in Greek (p. 28), who comes to be worshipped by the people as an incarnation of Ungit, the national deity (p.40)-. Orual shares in the popular adoration, but a series of calamities convinces the priests that the new cult has excited the wrath of Ungit, which can be appeased only if Psyche is abandoned on the mountain to glut the maw of an unnamed beast (p. 63). The rite is performed, and Psyche is presumed dead. Orual, however, induces Bardia the captain of the guard, to accompany her in a search for Psyche's bones (p. 101). To their astonishment, they find Psyche alive, and Orual fords a stream to

\footnotetext{
${ }^{37}$ From Ishtar, perhaps, or Astra? See above.
} 
hear her story. ${ }^{38}$ Psyche tells her that she was released from her bonds by a god whose bed she now shares in his sumptuous palace, where nothing is denied to her but the sight of her lover's face (pp. 121 and 132). Orual half believes her until, when she asks how far the palace is, she hears with dismay that they are sitting on its very steps (p. 125). Psyche is equally shocked to learn that Orual perceives nothing but natural scenery, and the two sisters part in sorrow (pp. 137-138). Orual now catches a glimpse of the palace, but can make nothing of the vision (pp. 141-143). Bardia, when he hears the story, opines that Psyche's bride is the beast in human guise (p. 145), while the Fox suspects that she has been seduced by a local bandit (pp. 152-153). Orual returns to the mountain with a knife and lamp, and urges Psyche to unmask and kill her deceitful paramour (pp. 172-176). From afar she witnesses a furious storm which tells her that the plan has been carried out too well ( $p$. $180)$. She tries to cross the stream, but is restrained by a god ${ }^{39}$ who announces that from now on she must be Psyche (p. 182).

The king dies slowly and Orual becomes queen (p. 223). Having worn a veil to conceal her identity when she visited Psyche, she decides to wear it on all occasions (pp. 189-190), thus gaining a reputation for beauty despite her natural ugliness (p. 237). She also becomes proficient in swordsmanship, killing the ruler of a neighbouring kingdom in single combat (p. 229). By setting his brother on the throne she also secures a husband for Redival, whom she sees no more (p. 235). Orual hears that in neighbouring Essur Psyche is worshipped as a veiled image and her fall retold in the manner of Apuleius (p. 251-255); even in Glome a beautiful statue of Ungit is created as a rival to the crude effigy that has satisfied the people for generations (p. 243-24). Orual hates Ungit all the more, and her narrative ends, as it began, with an indictment of the gods (p. 259). She takes up her pen, however, to write an epilogue, in which she dreams that a pile of seeds is set before her for sorting, and she executes the task by becoming an ant (pp. 266-267). She goes on to recount her interview with Bardia's widow shortly after his death, in which she learns for the first time that he had given his soul to her while she had regarded him, not with love, but with the jealousy of possession (pp. 270-273). Knowing that, in spite of all, she had never been able to disbelieve in Ungit like her tutor the Fox (p. 32), she observes the devotion of the

\footnotetext{
${ }^{38} \mathrm{Pp} .110-112$. The harrowing coldness of the water suggest that this might be the river of death. 39 Initially this was to be Psyche, transfigured into the "terrifying maternal goddess": Collected Letters, vol. 3 (Grand Rapids: Zondervan, 2007), 630. Cf. Neumann on Apuleius, above.
} 
common people and discovers that they still address their prayers to the rough-hewn image (pp. 281-283). In a dream ${ }^{40}$ she learns that Ungit is her true self which was hidden from her by her illusory self-image (pp.287-288). Again she tries to drown herself, and again a god restrains her (p. 290). Confident that her love for Psyche at least was selfless (p. 296), she finds herself in another dream, in which she is set the hopeless task of gathering golden wool from the rams of the gods (p. 294). Another woman passes the test by plucking threads of wool from the thorns on which the rams deposit them as they brush by (p. 295). Then an eagle carries her to the assembly of the gods, where she is invited to read her charge (pp. 298-300). She reads them again and again until she can say no more; when asked "Are you answered?" her reply is "Yes" (p. 304). In the final chapter the Fox, who has long been dead, shows her a series of visions, in which it is Psyche who undergoes the same ordeals (pp. 308-312). The last, which Psyche alone performs, is to bring back from hell the beauty that will make Ungit beautiful; ${ }^{41}$ the only part of this that does not come easily to the child is the repudiation of Orual's selfish love (p. 315). At last the sisters are reunited and the last word from heaven to Orual is "you are Psyche" (p. 319).

It should be clear from this summary that Lewis has taken none of his precursors for a model. The sisters had already come into their own in Morris and Couperus, but we cannot say that Orual is the counterpart of Athena like the younger sister in Morris, or that the veiling of Orual from the sight of others simply inverts the blindness of Astra. A structuralist, if Lewis could be shown to have read Couperus, would dwell on the opposition between the nakedness of Psyche and Orual's veil. Psyche's change of countenance in La Fontaine is another form of veiling, but it cannot be shown that Lewis was in his debt. It is interesting that a fox should be the counsellor of a princess in one of Basile's stories also, ${ }^{42}$ but we have no reason to think that Lewis was purposely alluding to this story. An unwitting echo is likely enough, as Lewis's fiction was always the precipitate of materials gathered casually and eclectically over decades, then subjected to new combinations and refinements in the crucible of the unconscious, so that he himself could not have named all the

\footnotetext{
${ }^{40}$ The psychopomp is her father, who hates her as much as the king loves Psyche in Couperus.

${ }^{41}$ P. 316 suggests that, as Neumann intimates, the gods gain something from intercourse with humans.

42 Day 2, story 5: a princess takes a husband who is a serpent to public view but a handsome prince when the two are alone. Deprived of his serpent skin by her father, the prince flies off in the form of a bird; after days of fruitless searching, she finds him again with the help of a vixen, whose blood proves to be a necessary ingredient in the medicine that restores him to human shape.
} 
ingredients or explained how they came to be there. A critical inquiry into the gestation of Till We Have Faces might be as long as the famous study of "Kubla Khan" by John Livingstone Lowes, ${ }^{43}$ and would be equally incapable at many points of distinguishing conscious from subconscious processes. Did Lewis reflect for example, that Psyche's account of her awakening on the mountainside (p. 117) would bring to mind the awakening of Snow White ${ }^{44} \mathrm{Had}$ he been haunted since childhood by the figure of Rider Haggard's Ayesha, whose veil conceals both a beautiful face and an adamantine soul, enabling her in youth to plot against tyrants with masculine vigour and then to rule an embattled realm for centuries without fear of insurrection. ${ }^{45}$ We may be sure at least that he was conscious of his own borrowings from Narnia, and especially from The Last Battle (another publication in 1956), in which the dwarfs refuse to see the new world that others have entered through the stable-door, and the hideous Tash is conflated with Aslan, ${ }^{46}$ just as Ungit is falsely depicted under the form of Psyche. Such remarks, however, while they shed light on the workings of imagination do not give us an answer of the kind that we are soliciting when we ask of a work of art, "What does it mean?"

But what would constitute meaning? Lewis did not share Tolkien's hatred of "allegory in all its manifestations"; ${ }^{47}$ his Allegory of Love, indeed, perhaps did more than any other book in the twentieth century to rescue this species of writing from neglect. ${ }^{48} \mathrm{We}$ cannot deny its presence in The Lion, the Witch and the Wardrobe, where Aslan, the lion who later appears as a lamb, offers his own life at the stone table for the child who has sinned against him; ${ }^{49}$ nor does Perelandra leave us in doubt that its hero, Ransom, received his surname because his destiny was to protect a new Adam and Eve from a human avatar of Satan. ${ }^{50}$ If Michael Ward is correct, the alchemical symbolism of the planets is the silent leitmotif of the Narnia chronicles. ${ }^{51}$ In Apuleius' tale of Cupid and Psyche, many readers feel

\footnotetext{
43 J. L. Lowes, The Road to Xanadu (Edinburgh: Constable, 1927).

44 In Disney rather than Grimm, perhaps; we may also consider the childhood of Psyche in Couperus.

45 See especially H. Rider Haggard, She (London: Longman, 1887) and Wisdom's Daughter (London: Doubleday, 1923).

${ }^{46}$ Lewis, The Last Battle (London: Collins, 1956), 133 and 168.

47 J.R.R. Tolkien, The Lord of the Rings (London: Harper Collins, 1991), 11.

${ }^{48}$ Lewis, The Allegory of Love (Oxford: Oxford University Press, 1936).

${ }^{49}$.Lewis, The Lion, the Witch and the Wardrobe (London: Collins, 1950), 156--176.

${ }^{50}$ Lewis, Perelandra (London:Pan, 1953), 134.

${ }^{51}$ M. Ward, Planet Narnia: The Seven Heavens in the Imagination of C.S. Lewis (New York: Oxford University Press, 2010).
} 
the necessity of an allegorical reading, yet none has been found satisfactory to all. Till We Have Faces has invited similar experiments, which have met with an equally mixed reception. In the following section of this paper, I shall take up the clue afforded by the name Psyche, with the caveat (familiar to all students of Apuleius) that the fullest application of the resultant allegory may not amount to a full exposition of the text.

\section{The symbolism of the veil}

One does not need any Greek to know that Psyche means "soul", and this is consequently the one invariant in allegorical readings of the story in Apuleius. It is generally expounded, in fact, as though Psyche and her hidden paramour were the only characters, the roaming bride and incognito Prince of Peace in a Latin Song of Songs. By contrast, any reading of Lewis' novel, where Psyche's sister is the narrator, will stand or fall by its ability to make sense of this third character. The clues to this, apart from the sibling tie, are Orual's blindness in the first half of the tale and her subterfuge in the second; she veils herself from the world as Psyche's world was veiled from her. Lewis's taste in literature might have led us to predict that it would have been Cupid who wore the veil, for he is the author of a penetrating article on a scene from Edmund Spenser in which the god wears a blindfold, thereby rendering himself immune to pity: ${ }^{52}$

Blindfold he was, and in his cruell fist A mortal bow and arrows keen did hold

(Faerie Queene III.11.48)

There is also a line in Spenser's correspondence to his mentor in Latin metres, Gabriel Harvey -

Wote ye, why his Mother with a Veale hath covered his Face? ${ }^{53}$

- of which the best that can be said is that it may have inspired a poem by Robert Bridges, one of Lewis's favourites in his student years. ${ }^{54}$ Yet the Cupid of Till We Have Faces (if we

\footnotetext{
52 Lewis, "Spenser's Cruel Cupid", in Studies in Mediaeval and Renaissance Literature (Cambridge: Cambridge University Press, 1966), 164.

${ }^{53}$ E. Spenser, Works, ed. R. Morris (London: Macmillan, 1909), 709.

${ }^{54}$ R. Bridges, Poetical Works, 348: "Why hast thou nothing in thy face/Thou idol of the human race?" See Lewis, Collected Letters, vol. 1 (San Francisco: Harper, 2004), 426 and the preface to Till We Have Faces. Bridges divided his Eros and Psyche into twelve cantos, each containing as many stanzas as there are days in the corresponding month.
} 
may call him that ${ }^{55}$ ) is a being without either name of visage, the God of mystics rather than mythology; one consequence of our seeing everything through the eyes of Orual is that we do not witness Psyche's indiscretion or the flight of her wounded bedmate. The fact that it is the woman, not the deity, who is veiled puts us in mind of an author whom Lewis prized more highly than either Spenser or Bridges, the apostle Paul. The most famous text, in which Paul says that nature enjoins a woman to wear a veil for the sake of the angels (1 Corinthians 11.10), is not the most pertinent: Orual does not hide her face in deference to custom, or to repel any gaze but that of her fellow-humans. The heart of the gospel for Paul is not the subjection of man or woman but the liberation of both by the removal of the bar to understanding that is represented by the veil of Moses as he comes down from Mount Sinai with the tables of the Law:

Seeing then that we have such hope, we use great plainness of speech; and not as Moses, which put a veil over his face, that the children of Israel could not steadfastly look to the end of that which is abolished. But their souls were blinded; for until this day remaineth the same veil untaken away in the reading of the old testament, which will be done away in Christ. But even unto this day, when Moses is read, the veil is upon their hearts (2 Corinthians 3.12-15, King James Version).

The veil on the hearts of the Jews is a disposition to read the Law carnally, not according to the Spirit whom Christ imparts to his disciples. Commentators hasten to assure us that the carnal state is not physical embodiment but the godless orientation of the will; to live in the flesh is to live in bondage, not only to worldly ignorance and base passions, but to an arrogant legalism which judges each of us according to our sins and therefore lays on all a yoke of obedience which none can bear (Acts 15.10). It is therefore the Pharisee rather than the prodigal who will always be deaf to the promise of deliverance - so afraid of being of being taken in that he cannot be taken out, as Lewis says of the dwarfs in The Last Battle. ${ }^{56}$ All this is true enough, but it is also true that Paul associates the fleshly state with the present conditions of embodiment. When he writes that he did not confer with flesh and blood before his journey to Jerusalem, he means that he did not consult the apostles (Galatians 1.16). When he declares that flesh and blood cannot enter the kingdom of heaven (1 Corinthians 15.50), he is answering the question "in what body will the dead rise?", and his response is that the spiritual body is not a replica of the psychic or animal body that enters the soil any more than the rising wheat is a replica of the seed that is sown

\footnotetext{
55 Lewis eschewed the name, pronouncing it "odious" at Collected Letters 3, 1295.

${ }^{56}$ Lewis, Last Battle, 136.
} 
in the furrow (1 Corinthians 15.44). The sinner who protests that "in me (that is, in my flesh), dwells no good thing" (Romans 7.18) ends by exclaiming "Who will deliver me from the body of this death?" (Romans 7.24). The author of the first commentary on Paul's letters represented the body of Christ himself as a veil that must be pierced if we are to pass from shadows to their archetypes in a higher realm:

Having therefore, brethren, boldness to enter into the holiest by the blood of Jesus, by a new and living way which he hath consecrated for us, through the veil, that is to say, his flesh, and having an High Priest over the house of God: let us draw near, with a true heart, in full assurance of faith, having our hearts sprinkled from an evil conscience, and our bodies washed with pure water. (Hebrews 10.19-22).

Christ in flesh is the unknown God, as Eros was the unknown god to Psyche. The author transfers to his person the symbolic unveiling of the Holy of Holies which accompanies his Passion in the three synoptic gospels. ${ }^{57}$ The heavenly city, dimly foreseen by the patriarchs as Orual caught a fugitive glimpse from afar of Psyche's palace, is the true abode of the all Christians (Hebrews 13.14): in the present world, however, they must cherish faith as the "substance of things hoped for, the evidence of things not seen" (Hebrews 11.1). So long as we inhabit this world, the veil is not removed from the eyes even after it has been lifted from the heart.

Is Orual then the body, the inseparable companion of soul? ${ }^{58}$ By "body", of course, one would mean, with Paul, the moribund residue of sin which is none the less destined, after it rises from the furrow, to be conformed to the glorious body of Christ (Philippians 3.21). Lewis had a vivid faith in the resurrection of the body: "Remember your fairy-tales", he says in "The Weight of Glory" to those who are still enchanted by the lie that "the good of man is to be found on this earth". ${ }^{59} \mathrm{He}$ goes on to declare that we live every day without knowing it in the visible presence of future gods and goddesses, adapting to his own purpose Augustine's comment on Psalm 36.8, "thou shalt make them drink of the river of thy pleasure": 60

The whole man is to drink joy from the fountain of joy. As St Augustine said, the rapture of the saved soul will "flow over" into the glorified body. In the light of our present specialized and depraved appetites, we cannot imagine this torrens voluptatis [river of thy pleasure], and I warn everyone

\footnotetext{
${ }^{57}$ Hebrews 9.3; cf. Matthew 27.51 etc.

${ }^{58} \mathrm{Cf}$. Fulgentius and Boccaccio on Apuleius, above. Both, of course, will have been well known to Lewis.

59 Lewis, The Essay Collection and other Short Pieces (London: Harper Collins, 2000), 100.

60 "Weight of Glory", 105-106.
} 
seriously not to try. But it must be mentioned, to drive out thoughts even more misleading, thoughts that what is saved is a mere ghost, or that the risen body lives in dumb insensibility. The body was made for the Lord and these dismal fancies are wide of the mark.

Augustine himself, ${ }^{61}$ when commenting on this verse, had observed that something great is promised, of which he could say only with Paul that "now we see through a glass darkly, but then face to face" (1 Corinthians 13.12). Lewis chose his title, "The Weight of Glory", to set off the cumbersome presence of the body in this world against its future sublimation. The epistle from which he drew it, however, Paul's second to the Corinthians, is the one in which the apostle speaks repeatedly of the difference between this darkness of the present life and the glory of things to come. The Israelites were awed by the glorious countenance of Moses (2 Corinthians 3.7), yet even this was nothing by comparison with the "glory that excelleth" (3.11), and it is when the veil is taken from our own faces that the infinite glory of God will begin to shine through the glass of vision:

Nevertheless, when it shall turn to the Lord, the veil shall be taken away, For the Lord is that Spirit; and where the Spirit of the Lord is, there is liberty. But we all, with open face beholding as in a glass the glory of the Lord, are changed into the same image from glory to glory, even as by the Spirit of the Lord (2 Corinthians 3.18).

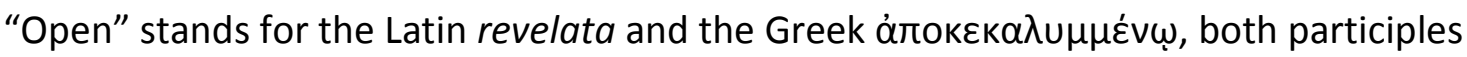
which signify the removal of a veil. For commentary it will suffice to quote Orual's question just before the eagle carries her into the divine assembly: "how can we know them face to face till we have faces?" 62 The glory to come is for Paul not a disembodied state but one in which the corruptible body of flesh gives way to a spiritual body, that is a body which is totally at the disposal of the Spirit. In this consummation flesh and soul are one, or in biblical terms, there is no law of sin in the members at war with the law of God in the mind (Romans 7.25). In one of his letters, Lewis hints that the function of myth is to bring us "up out of psyche into pneuma" by the work of imagination. ${ }^{63} \mathrm{He}$ adds that an author's gloss on a myth is seldom as good as the myth itself, unless it is drawn from the works of "other men, real thinkers"; thus we are only following his own precept if we turn to Paul for a gloss on the book that he himself had struggled to finish, let alone to explain.

\section{Concluding reflections}

\footnotetext{
${ }^{61}$ Enarrationes in Psalmos 35.14.

62 TWHF, 305.

${ }^{63}$ Lewis, Collected Letters, vol. 3, 390. He is commenting on Childhood's End by Arthur C. Clarke's
} 
While the people of Glome continue to worship Ungit, neglecting the image that belies her ugliness, the queen conceals her own ugliness under a veil, denying inwardly that she too is a child of the goddess. Philosophy, in both its Platonic and its Cartesian phases, has been apt to discount the body as a counterfeit self, the "shade of a shade", as Plotinus scoffed when asked to sit for his portrait. ${ }^{64}$ The second shade is the false self within, the creature of passion and circumstance; the higher soul, by contrast, is the "icon" of Nous or Intellect, as Nous in turn is an icon of the One. In Christian thought, the body is destined to rise again in the likeness of the glorified body of Christ (Philippians 3.21); in this life, however, it is governed by a law at odds with the law of the Spirit, a "body of death" as Paul exclaimed when he found himself unable to put away sin. Paul and the ascetics who read him closely were not traducing the creation but acknowledging the fall; the twentieth century, in denying original sin, has not rediscovered the body, for all its glorification of sexual intercourse and culinary pleasure. ${ }^{65}$ The moneyed class no longer teaches its children to ride, to fight or to ply the needle, and Ransom in Perelandra is dismayed when he learns that he must defeat his antagonist, the Un-man, not with his brain but in physical combat. ${ }^{66}$ If the body is to be redeemed, we must acknowledge that it is part of us, and hence that, like the soul, it must suffer before it can be transformed.

This is an argument for the resurrection, but it was Porphyry the Platonist who, according to Augustine, taught that embodiment was a necessary means to the education of the soul. ${ }^{67}$ Lewis, who in this respect was no Platonist, remembered that the body presents the soul not only with pains to be borne but with pleasures to be enjoyed: the soul "cries out for the resurrection of the senses", he exclaimed in Letters to Malcolm. ${ }^{68}$ Even our cast of mind is affected to some degree by the posture of the body: Screwtape scoffs at those who imagine that they can pray as fervently in bed as on their knees. ${ }^{69}$ Perhaps indeed it is not the body alone but its substratum, the all too human and bedrock of feeling, that is represented by Ungit and by Orual who shares the face of Ungit; perhaps, that is, the true opposition is not between soul and body but between the cold rationality of the Fox, Orual's

\footnotetext{
64 Porphyry, Life of Plotinus 1; cf. Plotinus, Enneads 1.1.12.

65 See C.S. Lewis, Mere Christianity (London: Bles, 1952), 95-98.

${ }^{66}$ Perelandra, 131.

${ }^{67}$ Augustine, City of God 10.30.

68 Lewis, Letters to Malcolm, Chiefly on Prayer (London: Collins, 1966), 121.

${ }^{69}$ Lewis, The Screwtape Letters (London: Collins, 1953), 25.
} 
Greek tutor, and the visceral sense of mighty and unseen forces which she shares with the simplest of her native people. Even the cities reared by the human intellect, Psyche tells her, rest on earth that is deeper than their foundations (p. 78). The Greek cherishes his serenity, like the gods whose properties he has ascertained by his own cogitations (p. 36); but might not the gods be greater, as Orual dares to wonder, ${ }^{70}$ if they too could feel ( $p$. 288)?

Lewis here approaches the psychological interpretation of Neumann, except that for Neumann there is nothing more ultimate than the subconscious. The paradox of a god in the world, by contrast, is as much a fact to the man of Essur as the subsequent deification of Psyche; as Athanasius put it, God became man that man might be god. ${ }^{71}$ The universality of this truth did not imply for Lewis that the taking of flesh in Christ was any less a historical fact than the birth of any other human. By the same principle Orual, as Lewis said, is rather a case than a symbol; ${ }^{72}$ she cannot be reduced to a single abstraction in the manner of Bunyan or Langland. Does this preclude an allegorical reading of the novel? The modern world - Tolkien perhaps included - prefers suggestive intimations to perfect correspondences; the symbolism embedded in the narrative is not an alphabetic key to the narrative itself. The atrophy of the European soul is exposed in Eliot's "Gerontion", ${ }^{73}$ while Thomas Mann's reflections on the moral decay of his country in Doctor Faustus suggest a political analogue to the slow incubation of his hero's syphilis; ${ }^{74}$ none of these works, for all that, can be plausibly understood as a roman à clef in the manner of Jonathan Swift. The work of Michael Ward on the Narnia Chronicles, however, would suggest that we have the right to adopt a more exacting method of decipherment in reading Till We Have Faces, so long as this is grounded in a system of recognised correlations to which the author is known to have subscribed.

\footnotetext{
${ }^{70}$ Cf. p. 74: "I wonder do the gods know what it feels like to be a man".

${ }^{71}$ On the Incarnation 54.3. See Lewis's introduction to P. Lawson, St Athanasius on the Incarnation (London: Bles, 1944).

72 Cf Lewis, Collected Letters 3, 831.

73 T.S Eliot, Complete Poems and Plays (London: Faber, 1969), 37-39.

${ }^{74}$ Thomas Mann, Doctor Faustus (Harmondsworth: Penguin, 1968), 288-292; 322-329.
} 
The example of Dante, whose characters often swell to three dimensions, is sufficient proof that we need not deny the term "allegory" to realistic fictions. ${ }^{75}$ If body and soul are personified archetypes in Till We Have Faces, they take on the nature of persons, as the Archetype of all humanity did when he broke into history, incarnating myth as fact. In this, as we have seen, Till We Have Faces resembles its prototype, yet the recognised failure of scholarship to achieve a complete decipherment of the tale of Cupid and Psyche ${ }^{76}$ has only deepened our conviction that there is something behind the glittering exterior which speaks to our condition. The appeal to depth psychology in the interpretation both of Apuleius and of Lewis is an anachronism in one case and an affront to the author's prejudices in another; it is none the less a recognition that Freud and Jung apply techniques in the clinic which were once ubiquitous in the Christian reading of both classical and biblical literature. ${ }^{77}$ Lewis, whose own work had brought the study, if not the practice, of such techniques into fashion again, was well aware that the "myth" which he was adapting had been a subject for mediaeval and early modern allegoresis; he was also aware that the Bible is not only the commonest subject of allegoresis but the canonical exemplar of this practice. For Paul or his imitators the veil may symbolise both the clandestine revelation of the Son of God in flesh and the occultation of the spirit beneath the letter of the Law; its salience in Till we have Faces not only invites us to read the tale as an allegory but prompts us to seek the key where any Christian would expect to find it hidden in plain sight.

\footnotetext{
${ }^{75}$ On the device of "figuration" see E. Auerbach, Mimesis: The Representation of Reality in Western Literature (Princeton: Princeton University Press, 1968), 174-202. For the description of the Divina Commedia as an allegory see Dante Alighieri, Letter to Can Grande della Scala 155-161, in Tutte le Opere, ed. E. Moore (Oxford: Oxford University Press, 1904), 415.

${ }^{76}$ See the "afterthoughts of Relihan, Cupid and Psyche, 68-85.

77 See Lewis, "Psychoanalysis and Literary Criticism", in Selected Literary Essays (Cambridge: Cambridge University Press, 1969), 274-300.
} 